\title{
THE ANALYSIS OF THE EFFECTS OF CAPITAL ADEQUACY RATIO, OPERATIONAL COST COMPARING TO THE OPERATIONAL REVENUE, NET INTEREST MARGIN, NON-PERFORMING LOAN AND LOAN TO DEPOSIT RATIO UPON THE RETURN ON EQUITY (Empirical Study of Company Banking registered in the List of BEI for the period of 2012-2015)
}

\author{
Gilang Ramadhan Fajri \\ Department of Accounting, Polytechnic of Bina Budaya Cipta (BBC), Sukabumi, Indonesia \\ gilangramdhanfajri@gmail.com (G. R. Fajri)
}

\begin{abstract}
Received: September 21, 2018; Accepted: October 19, 2018; Published: December 31, 2018
To cite this article: Gilang Ramadhan Fajri. The Analysis of The Effects of Capital Adequacy Ratio, Operational Cost Comparing to The Operational Revenue, Net Interest Margin, Non-Performing Loan and Loan to Deposit Ratio upon The Return On Equity (Empirical Study of Company Banking Registered in The List of BEI for The Period of 2012-2015), The Accounting Journal of BINANIAGA, Vol. 03, No. 02, December 2018, pp. 15-28.
\end{abstract}

\begin{abstract}
This research is an empiric study to do a research on the Analysis of the Effects of Capital Adequacy Ratio, Operational Cost comparing to the Operational Revenue, Net interest margin, Non-Performing Loan and Loan to Deposit Ratio upon the Return on Equity (Empirical Study on the Company Banking listed on BEI for the period of 2012-2015), sampling technique has applied the purposive sampling in order to get the samples of 30 companies. The aims of this research are to prove that the effects of Capital Adequacy Ratio (CAR), Operational costs comparing to the Operational Revenue (BOPO), Net interest Margin (NIM), Non-Performing Loan (NPL) netto and Loan to Deposti Ratio (LDR) upon the performance of bank which is measured by Return on Equity (ROE) and which variables that have been the most dominant affecting Return on Equity (ROE). The Analytical technics has applied multiple linear regression and hypothesis test has used $t$-statistics to examine partial regression coefficient and $f$-statistics to examine the feasibility of the research model using the level of significance of $5 \%$. Besides that, classical assumption test has been done covering normality test, multicollinearity test, heteroscedasticity test and auto correlation test.
\end{abstract}

Key words: Capital Adequacy Ratio (CAR), Operational Cost comparing to the Operational Revenue (BOPO), Net Interest Margin (NIM), NonPerforming Loan (NPL). Loan to Deposit Ratio (LDR), Return on Equity (ROE).

\section{INTRODUCTION}

\section{Background of the Research}

Nowadays, many companies banking have been done by a lot of the people in Indonesia. But it seems that many people still have not understood about the meaning, function and tasks of the bank itself. In general, banking is identical with finance which is savings, loans, clearing account, etc. The understanding of company banking is based on the Acts of the Republic of Indonesia Number 10-year of 1998, Bank is a business unit

Gilang Ramadhan Fajri. The Analysis of The Effects of Capital Adequacy Ratio, Operational Cost Comparing to The Operational Revenue, Net Interest Margin, Non-Performing Loan and Loan to Deposit Ratio upon The Return On Equity (Empirical Study of Company Banking Registered in The List of BEI for The Period of 2012-2015) 
collecting the money from the people which is savings and distributes it to the people as credit loan and or other types in order to improve the standard of people life. It can be concluded that the bank is a business unit owned either by the government or private one having bank's function and tasks to collect and to distribute some money to the people and to execute other activities related to the finance.

However, the understanding about bank referred to PSAK 31, Bank is an industry dealing business relying on people trustworthy, so that, the level of bank's healthy should have to be taken care obviously. The information about bank financial report is one of the efforts to support the business people evaluating the financial condition and performance of the bank. The financial report issued by the bank is the information resource to figure out the financial condition of the bank, its performance and financial condition changes. This financial report can be used as the measurement of bank's performance by executing the analysis of financial report.

The Financial performance is the reflection of company's achievement related to all the activities being done. It can be explained that the financial performance is an analysis being done to see how good a company has been doing its business using the regulation of finance implementation correctly and right (Fahmi, 2012:2). The same opinion was described by Sawir (2005:1) describing that the financial performance is the condition that has figured out a company's financial condition based on its target, standard and criteria stated.

This research is the continuation of my previous research applying the Financial ratio measurement, which is Capital Adequacy Ratio (CAR), Operational cost comparing to the Operational Revenue (BOPO), net interest margin (NIM), Non-Performing Loan (NPL) netto, Loan to Deposit Ratio (LDR), Return on Equity (ROE). The reasons why the writer has taken the related financial ratio are as follows; first, it is easy to understand only by looking at the development of financial condition of a bank periodically. Second, the financial ratio is a simple substitute of the information provided by the financial report. Third, Choosing Return on Equity (ROE) as dependent variable due to ROE being used has given the profitability figure of the company upon the total of its equity. The bigger the ROE, the more effective of the company is. However, ROE has had a weakness since it has not been applying the total amount of its liabilities in the calculation. This research aims to describe the financial performance of the bank based on the output. Anwar, $Y$ and Murwaningsari, E (2016), revealed that credit risk as measured by non-performing loan (NPL) has a significant influence on profitability in the banking industry listed on the Indonesia Stock Exchange (IDX).

\section{Research Problems Design}

Based on the previous research, it has been some variables affecting bank's performance. Therefore, it has to do the retest of the variables affecting bank's performance. Referring to the aforementioned descriptions, the problems that are going to be studied in this research are as follows;

1. Are there any partial significant effects of financial ratio of CAR, BOPO, NIM, NPL and LDR affecting bank's performance measured by ROE?

2. Are there any simultaneous significant effects of financial ratio of CAR, BOPO, NIP, NPL and LDR affecting the performance of the bank measured by ROE?

3. Which variables are the most dominant affecting the performance of bank measured by ROE?

\section{Aims of the Research and the Benefit of the Research}

\section{Aims of the Research.}

a. To study how big the effects of financial ratio of CAR, BOPO, NIM, NPL and LDR upon the performance of the bank measured by ROE has happened.

Gilang Ramadhan Fajri. The Analysis of The Effects of Capital Adequacy Ratio, Operational Cost Comparing to The Operational Revenue, Net Interest Margin, Non-Performing Loan and Loan to Deposit Ratio upon The Return On Equity (Empirical Study of Company Banking Registered in The List of BEl for The Period of 2012-2015) 
b. To obtain the empiric evidence about the effects of CAR, BOPO, NIM, NPL and LDR partially and simultaneously upon the performance of bank measured by ROE has happened.

c. To study which variables are the most dominant affecting the performance of the bank measured by ROE.

\section{The Benefit of the Research.}

Based on the background, problems design and aims of the research, it is expected to provide the following benefits:

a. Theoretical benefit

Result of the research is expected to be used as an input or additional knowledge and as an empiric evidence regarding the effects of financial ratio as the measurement tools upon the performance of Return on Equity of Public Banks in Indonesia and can be used as the references for the researcher who is going to do the same research or further one.

b. Practical Benefit

Company banking sector can use it as the basic of decision making of the financial policy in order to improve the company's performance, so that it can improve the company value.

c. Academical Benefit

Academically this research is expected to give the literature contribution in the finance and accounting. Besides that, it can enrich science development in finance at company banking.

\section{THEORETICAL DESIGN}

\section{Signaling Theory}

Signaling theory defined that a company having a good quality would give the signal to the market which is expected to be able to differentiate the quality of good company and bad one (Hartono, 2005). Therefore, the longer time of publishing the financial audit report would create unstable value of the share, however, the investor would consider it as audit delay as the company could not publish its financial report immediately which is it has caused a decreasing price of its shares. Referring to Maria Immaculatta (2006) the quality of investor decision is affected by the quality of information disclosed by the company about its financial report. The quality of the related information aims to reduce any asymmetric information occurred when the managers know better the internal information and the company's prospect rather than the external party of the company. The information about the level of company's bonds published is expected to be the signal of the company's financial condition and to figure out any possible risks will happen due to the company's liabilities.

The strength of this theory is that it could explain why the increasing price of the share is happened as the feedback of the improvement of the financial leverage. But the weakness of this model is that it could not explain the contrary connection between the probability and leverage. And the other weakness, it could not explain why the company which is having the potential improvement and high price of intangible assets should have to use a lot of loans instead of the company that does not use any loans. But, according to the theory, it is needed to reduce the effect of asymmetric information.

\section{Analysis of the Theory of the Financial Report}

Referring to Harahap (2009:297), Finance ratio is the figures obtained from the comparison between one account in the financial report and the other accounts which are having a relevant and significant connection. Referring to Simamora (2002:357), ratio analysis is an important thing to describe the significant connections of many compononents mentioned on the financial reports. The ratio is describing the

Gilang Ramadhan Fajri. The Analysis of The Effects of Capital Adequacy Ratio, Operational Cost Comparing to The Operational Revenue, Net Interest Margin, Non-Performing Loan and Loan to Deposit Ratio upon The Return On Equity (Empirical Study of Company Banking Registered in The List of BEI for The Period of 2012-2015) 
connection between a certain amount and other amount, and using an analytical tool which is the ratio that will describe or figure out either good or bad financial condition of the company to the analyst.

Referring to Fahmi (2011:133), in order to be able to interprete the result of ratio calculation, it requires the comparison. Actually, there are two ways to execute the comparison of company's financial ratio, :

1. Cross sectional approach, is an evaluation by comparing the ratios of one company with other similar company at the same time.

2. Time series analysis, is comparing the ratios of company's finance periodically. Comparison between the existing ratios and the previous one will figure out whether the company has improved or decreased.

Analysis of bank finance report is a part of bank analysis. Bank analysis is an analysis about the prospect and the risk of a company in order the bank can make a decision. However, bank analysis is supporting a decision making to execute the evaluation about the environment of company banking, its strategy and its financial performance. Some procedures should have to be followed to execute the analysis of bank financial report. According to Prastowo and Juliati (2008:58) the following procedures should have to be done:

1. Understanding the background of company's financial data including its business type, applicable accountancy policy of the company.

2. Understanding the conditions which have been affecting the company. Such the conditions should have to be well understood including the information about the trend of the industry where the company is working on it which is technology change, consumer intention change, economic factors change such as change of income per capita, interest rate, inflation rate and taxes, as well as the changes happened in the company itself such as key management change.

3. Studying and reviewing the finance report of the bank. These seven steps are to ensure that the financial report of the bank has figured out the relevant financial data and is compliance with the applicable Finance and Accountancy Standard.

4. Analyzing the financial report of the bank after fully understanding all the company's profile and reviewing its financial report. However, by applying all the various available method and analysis technics you can analyze bank financial report and interpreted the result of analysis (if possible, accompanied by the recommendation)

\section{Return on Equity (ROE)}

Return on Equity (ROE) is the ratio of the comparison between net profit and the equity. The following equation is applied:

$$
\text { Return On Equity(ROE) : } \frac{\text { Net profit }}{\text { Equity }}
$$

This ratio is to measure how many percentage of net profit has been gained if it is measured from the owner's capital. According to Harahap (2009:305) the bigger ratio, the better result is, as the company is considered effective using its equity to gain the profit.

\section{Capital Adequacy Ratio (CAR)}

Capital Adequacy Ratio is the ratio of the capital indicating the capability of the bank to provide the finance to develop the business needs and to take any responsibility of the risk of the losses due to the operational bank. The bigger ratio, the better capital position is happened (Achmad and Kusuno, 2003). Referring to the Regulation of Bank of Indonesia Number 10/15/PBI/2008 chapter 2 artile 1, it mentioned that bank is obliged to provide minimum capital of $8 \%$ out of the considerate assets according to the risk (ATMR), CAR is the ratio indicating how big the risk of the bank assets is (credits,

Gilang Ramadhan Fajri. The Analysis of The Effects of Capital Adequacy Ratio, Operational Cost Comparing to The Operational Revenue, Net Interest Margin, Non-Performing Loan and Loan to Deposit Ratio upon The Return On Equity (Empirical Study of Company 
participation, commercial paper, invoices for other banks) which is financed by its owned capital, besides of the receiving some funds from external resources of the bank.

Capital Adequacy Ratio (CSR) equation is as follows:

$$
C A R=\frac{\text { Its owned capital }}{\text { ATMR }} \times 100 \%
$$

\section{Operational cost compared with the operational revenue (BOPO)}

BOPO is included in the rentability/profitability ratio (earnings). The success of a bank is based on the quantitative evaluation upon the bank profitability which can be measured by using the ratio of the operational cost against the operational revenue (Kuncoro and Suhardjono, 2002). Referring to Dendawijaya (2005), ratio of operational cost is applied to measure the level of the efficiency and the capability of the bank performing its operational activities. The ratio of operational cost against the operational revenue (BOPO) is usually named the ratio of efficiency applied to measure the capability of bank management controlling the operational cost against the operational revenue. The smaller the ratio, the more efficient of the operational cost performed by the related bank. (Almilia and Herdiningtyas, 2005)

$\mathrm{BOPO}$ is described on the following equation:

$$
\text { BOPO }=\frac{\text { Operational cost }}{\text { Operational revenue }} \times 100 \%
$$

\section{Net Interest Margin (NIM)}

Net Interest Margin (NIM) is the measurement of the differences between interest rate earning received by the bank or other financial authority and the value of the interest rate paid to the investor (e.g. deposit save), relatively to the total amount (productive interest rate) of the assets. It is similar with the gross margin of non-financial company.

$$
\mathrm{NIM}=\frac{\text { Net Interest revenue }}{\text { Productive assets }} \times 100
$$

\section{Non-Performing Loan (NPL)}

NPL is the debtors or a group of debtors who are in the class of $3,4,5$ out 5 credit class which is the debtors who cannot pay immediately, are doubted and cannot pay back anymore. It has to keep in mind that the changing of credit classification from current assets to NPL has happened gradually thru the process of degradation of credit quality (Z.Dunil, 2005).

$$
\mathrm{NPL}=\frac{\text { Credit problem }}{\text { Total Credit }} \times 100 \%
$$

\section{Loan to Deposit Ratio (LDR)}

Referring to Dendawijaya (2005) Loan to Deposit Ratio (LDR) has identified how good the capability of bank to pay back the funds of the depositors who withdraw their money which is using the credit given as the liquidity sources. Suppose the bank is able to distribute all the money that have been collected, it is profitable, but it will be the risk when the owners of the money withdraw their money or if the people who receive the loan cannot payback their loan. On the contrary, if the bank cannot distribute the money, it is going to face the risk because of losing the chance to get the profit, the limit of loan given by the bank is $80 \%$ and $110 \%$ maximum.

Gilang Ramadhan Fajri. The Analysis of The Effects of Capital Adequacy Ratio, Operational Cost Comparing to The Operational Revenue, Net Interest Margin, Non-Performing Loan and Loan to Deposit Ratio upon The Return On Equity (Empirical Study of Company Banking Registered in The List of BEI for The Period of 2012-2015) 


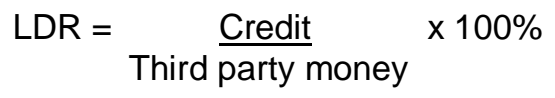

\section{THE RESEARCH METHODOLOGY}

\section{Type of the Research}

In this research, the researcher has applied causal research type to examine the hypothesis about the effects of five independent variables upon a dependent variable.

\section{Definition and Operational Variable}

\section{Dependent Variable}

Dependent variable is the variable being affected or created by independent variables. The dependent variable is Return on Equity (ROE).

3. Independent Variables.

Independent variables are the variables affecting the dependent variable. The independent variables of this research are Capital Adequacy Ratio (CAR), Operational cost comparing to the Operational Revenue (BOPO), Net Interest Margin (NIM), Non-Performing Loan (NPL) and Loan to Deposit Ratio (LDR).

\section{Measuring the Variables}

Variable has a definition of measurement or the characteristics of the members of the group that are different from the other groups. Another meaning of the variable is that something being used as the characteristic or the measurement obtained by a research regarding the particular concept. Measuring the Variable is the process to determine the total or the information intensity of someone, event, idea and or a particular object along with its connection with the problem or business prospect. On the other words, using the process of a measurement is to define the figures or tables against the characteristics or attributes of an object, or every phenomenon type or the event which are using a certain procedure to identify the total and or quality of the factors being studied.

\section{The Population and Samples of the Research}

Population is a general area consisting of objects or subjects having a specific quality and characteristic defined by the researcher to be studied and then to be concluded (Sugiyono, 2010). But the samples of the research according to (Margono, $2004: 121$ ), the samples of a research have come out due to:

1. The researcher is going to reduce the objects of the research due to a big population, so that, only a part of it to be studied.

2. The researcher is going to generalize the result of his research to define the conclusions upon the objects, symptoms, or events more extensive.

\section{Method of Data Collection}

Method of Data Collection that is applied in this research is an observation method which is the technics of data collection applying the observation upon the aspects of historical notes or recent notes of the public or private company. This research has collected the data by doing an observation, taking a note and analyzing the financial report of the companies banking listed on the website of Indonesian Stock Exchange, PT, which is www.idx.co.id.

Gilang Ramadhan Fajri. The Analysis of The Effects of Capital Adequacy Ratio, Operational Cost Comparing to The Operational Revenue, Net Interest Margin, Non-Performing Loan and Loan to Deposit Ratio upon The Return On Equity (Empirical Study of Company Banking Registered in The List of BEI for The Period of 2012-2015) 


\section{RESULT OF ANALYSIS AND DESCRIPTION}

\section{Descriptive Analysis}

This research is using the companies banking listed on Indonesian Stock Exchange, PT as the samples of the research which is based on the applicable samples criteria and sampling procedure about 30 companies and 120 samples during the observation period of time.

\section{Descriptive Statistics}

\begin{tabular}{|l|r|r|r|r|r|}
\hline & \multicolumn{1}{|c|}{$\mathrm{N}$} & \multicolumn{1}{c|}{ Minimum } & \multicolumn{1}{c|}{ Maximum } & \multicolumn{1}{c|}{ Mean } & \multicolumn{1}{c|}{ Std. Deviation } \\
\hline CAR & 120 & .1009 & .8749 & .185844 & .0906013 \\
\hline BOPO & 120 & .5993 & 1.7380 & .865716 & .1549703 \\
\hline NIM & 120 & .0024 & .1010 & .050089 & .0167966 \\
\hline NPLNeto & 120 & .0000 & .0545 & .013046 & .0109077 \\
\hline LDR & 120 & .4346 & 1.1330 & .820673 & .1325294 \\
\hline ROE & 120 & -1.4248 & .3866 & .100039 & .1917872 \\
\hline Valid N (listwise) & 120 & & & & \\
\hline
\end{tabular}

1. The means value (CAR) of 120 samples is 0.185 or $18.5 \%$ which is bigger than the standard of deviation value of 0.09 which means the companies banking on average has had the capital of 0.185 times out of the ATMR (Considerate Assets due to the Risk) which is $0.185: 1$ or on the other words, each Rp 1 of ATMR is guaranteed on average by the capital owned by the company about Rp 0.185 .

2. Means value (BOPO) of 120 samples is 0.865 or $86.5 \%$ which is bigger than the standard of deviation value of 0.154 which means that the companies banking on average are having the operational revenue of 0.865 times out of the operational cost (0.865: 1$)$ or every $\mathrm{Rp} 1$ of the operational revenue on average is guaranteed by $\mathrm{Rp} 0.865$ of the operational cost.

3. Means value (NIM) of 120 samples is 0.05 or $5 \%$ which is lower than the standard deviation value of 0.167 which means that the companies banking on average is having the productive assets of 0.05 times out of the net interest revenue $(0.05: 1)$ or every Rap 1, - of productive assets on average has gained $R p 0.05$ of net interest revenue.

4. Means value (NPL net) of 120 samples is 0.13 or $13 \%$ which is bigger than the standard deviation value of 0.109 which means that the companies banking on average is having total of the credit of 0.13 times out of the non-payable loan $(0.13$ : 1) or every $\mathrm{Rp} 1$,- of the total credit on average has gained $\mathrm{Rp} 0.13$ of the nonpayable loan. Non-payable loan is one of the key indicators to evaluate the performance of bank function.

5. Means value of (LDR) of 120 samples is 0.82 or $82 \%$ which is bigger than the standard deviation value of 0.132 which means that the companies banking on average is having the third-party money of 0.82 times out of the credit total $(0.82: 1)$ or on every Rp 1 of the third-party money has increased Rp 0.82 of the total credit.

6. Means value of (ROE) of 120 samples is 0.1 or $10 \%$ which is lower than the standard deviation value of 0.191 which means that the companies banking on average is having net profit of 0.1 times out of the equity $(0.1: 1)$ or on the other words, every Rp 1.- of the equity on average has gained $\mathrm{Rp} 0.1$ net profit.

Gilang Ramadhan Fajri. The Analysis of The Effects of Capital Adequacy Ratio, Operational Cost Comparing to The Operational Revenue, Net Interest Margin, Non-Performing Loan and Loan to Deposit Ratio upon The Return On Equity (Empirical Study of Company Banking Registered in The List of BEI for The Period of 2012-2015) 


\section{Classical Assumption Test}

\section{Normality Test of Probability Plot}

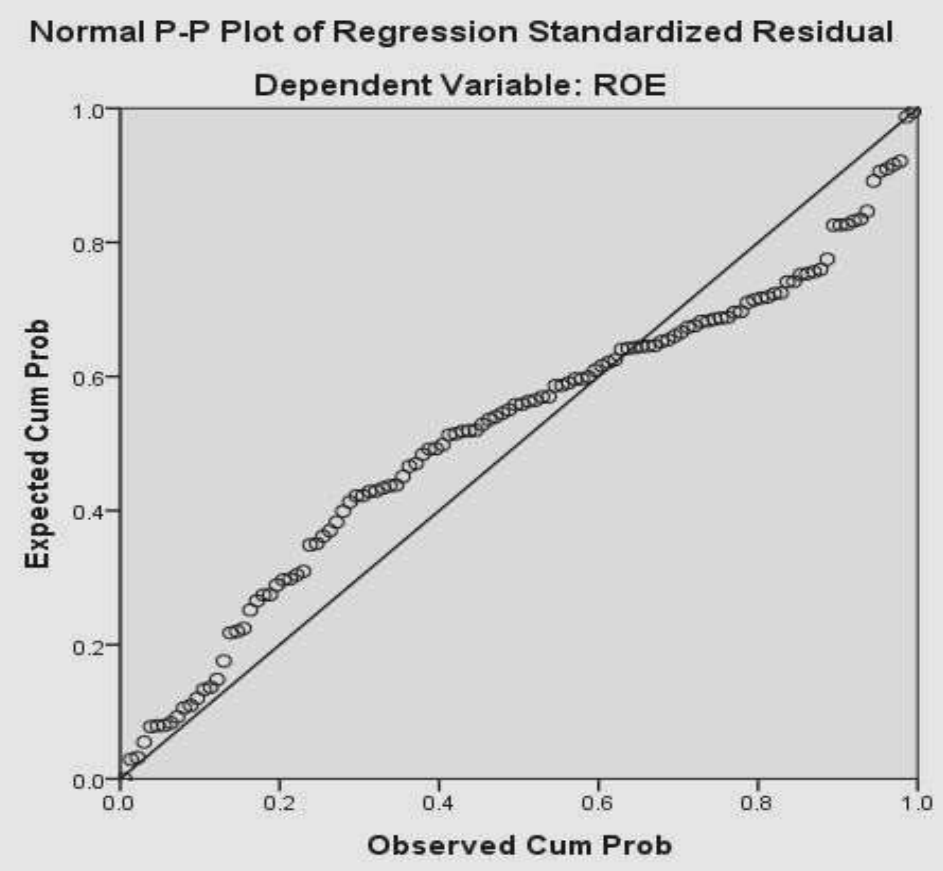

The aforementioned graph has indicated that the plots are scattering surrounding the line and are in line with the diagonal line, so that, the residual value is distributed normal.

\section{Multicollinearity Test}

Coefficients $^{\mathrm{a}}$

\begin{tabular}{|c|c|c|c|c|c|c|c|c|}
\hline \multirow{2}{*}{\multicolumn{2}{|c|}{ Model }} & \multicolumn{2}{|c|}{$\begin{array}{l}\text { Unstandardized } \\
\text { Coefficients }\end{array}$} & \multirow{2}{*}{$\begin{array}{c}\begin{array}{c}\text { Standardized } \\
\text { Coefficients }\end{array} \\
\text { Beta }\end{array}$} & \multirow[b]{2}{*}{$\mathrm{t}$} & \multirow[b]{2}{*}{ Sig. } & \multicolumn{2}{|c|}{ Collinearity Statistics } \\
\hline & & $\mathrm{B}$ & Std. Error & & & & Tolerance & VIF \\
\hline \multirow[t]{6}{*}{1} & (Constant) & 1.204 & .084 & & 14.261 & .000 & & \\
\hline & CAR & -.057 & .089 & -.027 & -.639 & 524 & .765 & 1.307 \\
\hline & BOPO & -1.192 & .065 & -.963 & -18.370 & .000 & .496 & 2.016 \\
\hline & NIM & -.649 & .568 & -.057 & $\begin{array}{l}-1.143 \\
\end{array}$ & 255 & .551 & 1.814 \\
\hline & NPLNeto & .434 & .775 & .025 & .559 & 577 & .701 & 1.426 \\
\hline & LDR & -.042 & .063 & -.029 & -.675 & .501 & .721 & 1.388 \\
\hline
\end{tabular}

The output above has indicated that the tolerance value of all the variables are bigger than 0.05 and the value of variance inflation factor (VIF) of all variables is less than 10 . So that, it is concluded that there is not any multicollinearity happened among the independent variables. However, the five variables can be used to predict the value of return on equity $(\mathrm{ROE})$ during the observation period. 


\section{Heteroscedasticity test (Correlation method of Spearman's rho)}

\section{Correlations}

\begin{tabular}{|c|c|c|c|c|c|c|c|c|}
\hline & & & CAR & $\mathrm{BOPO}$ & NIM & $\begin{array}{c}\text { NPLNe } \\
\text { to }\end{array}$ & LDR & $\begin{array}{c}\text { Unstandar } \\
\text { dized } \\
\text { Residual }\end{array}$ \\
\hline \multirow[t]{18}{*}{$\begin{array}{l}\text { Spearman's } \\
\text { rho }\end{array}$} & \multirow[t]{3}{*}{ CAR } & $\begin{array}{l}\text { Correlation } \\
\text { Coefficient }\end{array}$ & 1.000 & .034 & .096 & $-.293^{* *}$ & $-.203^{*}$ & -.117 \\
\hline & & Sig. (2-tailed) & & .716 & .298 & .001 & .026 & .203 \\
\hline & & $\mathrm{N}$ & 120 & 120 & 120 & 120 & 120 & 120 \\
\hline & \multirow[t]{3}{*}{ BOPO } & $\begin{array}{l}\text { Correlation } \\
\text { Coefficient }\end{array}$ & .034 & 1.000 & $-.661^{* *}$ & $.226^{*}$ & -.107 & $.506^{* *}$ \\
\hline & & Sig. (2-tailed) & .716 & & .000 & .013 & .245 & .000 \\
\hline & & $\mathrm{N}$ & 120 & 120 & 120 & 120 & 120 & 120 \\
\hline & \multirow[t]{3}{*}{ NIM } & $\begin{array}{l}\text { Correlation } \\
\text { Coefficient }\end{array}$ & .096 & $-.661^{* *}$ & 1.000 & -.068 & .175 & $-.195^{*}$ \\
\hline & & Sig. (2-tailed) & .298 & .000 & & .457 & .055 & .033 \\
\hline & & $\mathrm{N}$ & 120 & 120 & 120 & 120 & 120 & 120 \\
\hline & \multirow[t]{3}{*}{ NPLNeto } & $\begin{array}{l}\text { Correlation } \\
\text { Coefficient }\end{array}$ & $-.293^{* *}$ & $.226^{*}$ & -.068 & 1.000 & $.184^{*}$ & .160 \\
\hline & & Sig. (2-tailed) & .001 & .013 & .457 & & .045 & .080 \\
\hline & & $\mathrm{N}$ & 120 & 120 & 120 & 120 & 120 & 120 \\
\hline & \multirow[t]{3}{*}{ LDR } & $\begin{array}{l}\text { Correlation } \\
\text { Coefficient }\end{array}$ & $-.203^{*}$ & -.107 & .175 & $.184^{*}$ & 1.000 & .064 \\
\hline & & Sig. (2-tailed) & .026 & .245 & .055 & .045 & & .485 \\
\hline & & $\mathrm{N}$ & 120 & 120 & 120 & 120 & 120 & 120 \\
\hline & \multirow{3}{*}{$\begin{array}{l}\text { Unstandar } \\
\text { dized } \\
\text { Residual }\end{array}$} & $\begin{array}{l}\text { Correlation } \\
\text { Coefficient }\end{array}$ & -.117 & $.506^{* *}$ & $-.195^{*}$ & .160 & .064 & 1.000 \\
\hline & & Sig. (2-tailed) & .203 & .000 & .033 & .080 & .485 & \\
\hline & & $\mathrm{N}$ & 120 & 120 & 120 & 120 & 120 & 120 \\
\hline
\end{tabular}

${ }^{* *}$. Correlation is significant at the 0.01 level (2-tailed).

*. Correlation is significant at the 0.05 level (2-tailed).

The output above has explained that the correlation between the variables of CAR, NIM, NPL, LDR and the Residual Unstandardized is having the significant value (sig 2 tailed) more than 0.05 , since the significant value is bigger than 0.05 , it can be concluded that there is not any heteroscedasticity problems happened, but if the variable of BOPO has the significant value of less than 0.05 , then the related variable is having the heteroscedasticity problem.

\section{Autocorrelation Test}

\begin{tabular}{|l|c|r|c|r|r|}
\hline Model Summary \\
\hline Model & R & R Square & $\begin{array}{c}\text { Adjusted R } \\
\text { Square }\end{array}$ & $\begin{array}{c}\text { Std. Error of the } \\
\text { Estimate }\end{array}$ & Durbin-Watson \\
\hline 1 & $.919^{\mathrm{a}}$ & .844 & .838 & .0772710 & 2.058 \\
\hline
\end{tabular}

a. Predictors: (Constant), LDR, BOPO, CAR, NPLNeto, NIM

b. Dependent Variable: ROE

Test result of Durbin-Watson is 2.059, but on the table of Durbin-Watson (DW) $\mathrm{k}=6$ and $\mathrm{N}=120$, total of Durbin-Watson - table: $\mathrm{dl}$ (outer limit) $=1.6164$ and du (inner limit) $=1.7896 ; 4-d u=2.2104$ and $4-\mathrm{dl}=2.3836$. Therefore, the value of DurbinWatson (DW) of 2.058 is bigger than the limit (du) of 1.7896 and Durbin-Watson (DW) is less than 2.2104, then, it can be concluded that Durbin-Watson (DW) test can not reject $\mathrm{HO}$ describing that there is not any either positive or negative autocorrelation or there is not any autocorrelation happened.

Gilang Ramadhan Fajri. The Analysis of The Effects of Capital Adequacy Ratio, Operational Cost Comparing to The Operational Revenue, Net Interest Margin, Non-Performing Loan and Loan to Deposit Ratio upon The Return On Equity (Empirical Study of Company Banking Registered in The List of BEI for The Period of 2012-2015) 


\section{Multiple Regression Analysis}

\section{Determination Coefficient Test $\left(\mathbf{R}^{2}\right)$}

Model Summary

\begin{tabular}{|l|r|r|r|r|r|}
\hline Model & $\mathrm{R}$ & $\mathrm{R}$ Square & Adjusted R Square & $\begin{array}{c}\text { Std. Error of the } \\
\text { Estimate }\end{array}$ & Durbin-Watson \\
\hline 1 & $.919^{\mathrm{a}}$ & .844 & .838 & .0772710 & 2.058 \\
\hline
\end{tabular}

a. Predictors: (Constant), LDR, BOPO, CAR, NPLNeto, NIM

b. Dependent Variable: ROE

It means that the effect of independent variables upon the dependent variable which is Return on Equity (ROE) is 0,838 or $83.8 \%$. However, the rest of the value of 0.167 or $16.7 \%$ is explained by other variables which are not included in this research.

\section{2. f-test (simultaneously effect test)}

ANOVA $^{a}$

\begin{tabular}{|l|l|c|c|c|c|c|}
\hline \multicolumn{1}{|c|}{ Model } & Sum of Squares & Df & Mean Square & $\mathrm{F}$ & Sig. \\
\hline 1 & Regression & 3.696 & 5 & .739 & 123.817 & $.000^{\mathrm{b}}$ \\
\cline { 2 - 7 } & Residual & .681 & 114 & .006 & & \\
\cline { 2 - 7 } & Total & 4.377 & 119 & & & \\
\hline
\end{tabular}

a. Dependent Variable: $\mathrm{ROE}$

b. Predictors: (Constant), LDR, BOPO, CAR, NPLNeto, NIM

The result of the calculation has gained the value of $F$-count of 123,817 and $P$ value of 0.000 . It means that $P$ value is less than 0.05 and $F$-count is 123,817 which is bigger than $\mathrm{F}$ table of 2,293 ( $\mathrm{F}$ table $=\mathrm{F}(\mathrm{k}, \mathrm{n}-\mathrm{k})$, so that, it can be concluded that the hypothesis is accepted which is the variables of CAR, BOPO, NIM, NPL and LDR simultaneously have affected ROE.

\section{3. t-test (test of the effect partially)}

\begin{tabular}{|c|c|c|c|c|c|c|}
\hline \multicolumn{7}{|c|}{ Coefficients $^{\mathrm{a}}$} \\
\hline \multirow{2}{*}{\multicolumn{2}{|c|}{ Model }} & \multicolumn{2}{|c|}{ Unstandardized Coefficients } & $\begin{array}{c}\text { Standardized } \\
\text { Coefficients }\end{array}$ & \multirow[b]{2}{*}{$\mathrm{t}$} & \multirow[b]{2}{*}{ Sig. } \\
\hline & & $\mathrm{B}$ & Std. Error & Beta & & \\
\hline \multirow[t]{6}{*}{1} & (Constant) & 1.204 & .084 & & 14.261 & .000 \\
\hline & CAR & -.057 & .089 & -.027 & -.639 & .524 \\
\hline & BOPO & -1.192 & .065 & -.963 & -18.370 & .000 \\
\hline & NIM & -.649 & .568 & -.057 & -1.143 & .255 \\
\hline & NPLNeto & .434 & .775 & .025 & .559 & .577 \\
\hline & LDR & -.042 & .063 & -.029 & -.675 & .501 \\
\hline
\end{tabular}

Basic of decision making of t-test

a. If the value of sig $<0.05$ or $-t$ table $<t$ count $<t$ table, so that, variable $X$ has affected $\mathrm{Y}$.

b. If the value of sig $>0.05$ or $-t$ count $<-t$ table or $t$ count $>t$ table, it explains that variable $\mathrm{X}$ has not affected $\mathrm{Y}$.

The formulation of $t$ table $=t(\alpha / 2 ; n-k-1)=t(0,025: 114)=1.981$

\section{a. Test result of the effect of CAR (X1) upon ROE (Y)}

Since the Sig value of the effect of CAR (X1) upon ROE $(Y)$ is $0.524>0.05$ and $t$ count value is $-0.639>-1.981$, it is concluded that the variable CAR has contributed ROE. The value of $t$ negative has indicated that CAR is having the opposite connection with ROE. It can be concluded that CAR negatively and significantly has affected ROE.

Gilang Ramadhan Fajri. The Analysis of The Effects of Capital Adequacy Ratio, Operational Cost Comparing to The Operational Revenue, Net Interest Margin, Non-Performing Loan and Loan to Deposit Ratio upon The Return On Equity (Empirical Study of Company Banking Registered in The List of BEI for The Period of 2012-2015) 


\section{b. Test result of the effect $B O P O(X 2)$ upon ROE (Y)}

Since the value of sig of the effect of BOPO (X2) upon ROE (Y) is $0.00<$ 0.05 and the value of $t$ count is $-18,370<-1,981$, so that, it can be concluded that the variable of BOPO has not contributed ROE. The value of $t$ negative has indicated that BOPO has had an opposite connection with ROE. So that, it can be concluded that BOPO has not affected significantly ROE.

\section{c. Test result of the effect of NIM (X3) upon ROE (Y)}

Since the sig value of the effect of NIM (X3) upon ROE (Y) is $0.255>0.05$ and the value of $t$ count is $1,143>-1,981$, it is concluded that the variable NIM has contributed ROE. The value of $t$ negative has indicated that NIM has had an opposite connection with ROE. It is concluded that NIM has affected negatively and significantly ROE.

\section{d. Test result of the effect of NPL netto (X4) upon ROE(Y)}

Since sig value of the effect of NPL netto $(X 4)$ upon ROE $(Y)$ is $0.577>0.05$ and the value of $t$ count is $0,559<1,981$, it is concluded that the variable of NPL netto has contributed ROE. The value of $t$ positive has indicated that NPL netto has connected at the same direction with ROE. So that, it is concluded that NPL netto has affected positively and significantly ROE.

\section{e. The Test result of the effect LDR X5) upon ROE(Y)}

Since the sig value of the effect of LDR (X5) upon ROE (Y) is $0.501>0.05$ and the value of $t$ count is $-0.675>-1,981$, it is concluded that the variable of LDR has contributed ROE. The value of $t$ negative has indicated that LDR has had the opposite direction with ROE. So that, it is concluded that LDR has affected negatively and significantly ROE.

\section{CONCLUSION AND SUGGESTION}

\section{Conclusion}

1. CAR has affected negatively ROE, this condition indicates that the bigger CAR of a company is happened, the lower ROE of the related company will happen.

2. BOPO has affected negatively ROA, this condition indicates that the bigger BOPO of the company is happened, the lower ROE of the company will happen.

3. NIM has affected negatively ROE, this condition indicates that the bigger NIM of the company is happened, the lower ROE of the company will happen.

4. NPL netto has affected positively ROA. This condition has indicated that the bigger NPL netto of the company is happened, the bigger ROE of the company will happen.

5. LDR has affected negatively ROE, this condition has indicated that the bigger LDR of a company is happened, the lower ROA of the company will happen.

\section{Suggestions}

1. This research has been done only on the companies banking listed on Indonesian Stock Exchange, PT during 2012 - 2015, the next research can perform the research using different objects, e.g. the companies of mining sector and industry sector, manufacturing sector, property sector or agriculture sector to get a consistent result of the research.

2. This research has only applied Return on Equity (ROE) to evaluate the performance of the company. Furthermore, it is expected to enlarge the

Gilang Ramadhan Fajri. The Analysis of The Effects of Capital Adequacy Ratio, Operational Cost Comparing to The Operational Revenue, Net Interest Margin, Non-Performing Loan and Loan to Deposit Ratio upon The Return On Equity (Empirical Study of Company Banking Registered in The List of BEI for The Period of 2012-2015) 
research by evaluating the financial ratio, liquidity ratio, solvability ratio and other ratio which can be used to evaluate the company performance such as combing one of the variables with the other variables which are not included in this research in order to get the result more variety to figure out any matters affecting Return on Equity.

\section{REFERENCES}

Achmad, TK. (2003). Analysis of financial ratios as an indicator to predict the potential bankruptcy of companies banking in Indonesia, Media Ekonomi dan Bisnis, XV (1), pp 54-75.

Agnes, S. (2005). Analysis of Finance Performance and Planning the company finance, PT Gramedia Pustaka, Jakarta.

Almilia, L. S. and Winny, H. (2005). Analysis Ratio CAMEL upon the prediction of difficult problems at the institution of banking for the period of 2000-2002, Jurnal Akuntansi dan Keuangan, 7 (2).

Anwar, Y and Murwaningsari, E. (2016). The Effect of Credit Risk and Capital Adequacy Ratio Upon Return on Asset (A Case Study at Banking Listed in Indonesia Stock Exchange), The Accounting Journal of Binaniaga. 2 (2), pp 23-38.

Dendawijaya, L. (2005). Banks Management, the $2^{\text {nd }}$ edition, Ghalia Indonesia, Bogor.

Dunil, Z. (2005). Bank Auditing Risk-Based Audit in the Audit of Credit Public Bank, PT. Indeks Kelompok Gramedia. Jakarta.

Fahmi, I. (2012). Introduction of Stock Market, first edition, Alfabeta, Bandung.

(2011). Analysis of Finance Report, Lampulo, Alfabeta, Bandung.

Ghozali, I. (2013). Application of Multivariate analysis using the program of IBM SPSS 21, $7^{\text {th }}$ edition.

Harahap, SS. 2009. Critical Analysis of the finance report. Jakarta: RajaGrafindo Persada.

Simamora, H. (2002). Management Accounting, 2nd edition, UPP AMP YKPN, Jakarta.

Jogiyanto, H. (2005). Analysis and Design of Information System, $3^{\text {rd }}$ editior, Yogyakarta: ANDI.

Margono. (2004). Methodology of Educational Research, Jakarta: PT Rineka Cipta.

Mudrajad, K and Suhardjono. 2002. Banking Management, Yogyakarta: BPFE. (2004). Banking Management, Yogyakarta: BPFE.

Prastowo, D and Rifka, J. (2008). Analysis of Finance Report; Concept and Application, $2^{\text {nd }}$ edition, Yogyakarta: UPP STIM YKPN.

Restuti, MI. (2006). The Effect of Company Development upon the Leverage of Bonds and yield of Bonds, Jurnal Akuntansi dan Keuangan, Vol. 1 No. 3, 2007.

Gilang Ramadhan Fajri. The Analysis of The Effects of Capital Adequacy Ratio, Operational Cost Comparing to The Operational Revenue, Net Interest Margin, Non-Performing Loan and Loan to Deposit Ratio upon The Return On Equity (Empirical Study of Company 
Sugiyono. (2010). Research Method of the Education by Quantitative, Qualitative and R \& $D$ approach, Bandung, Alfabeta.

www.idx.co.id.

www.sahamok.com 
The Accounting Journal of BINANIAGA Vol. 03, No. 02, December 2018

PISSN: $2527-4309$

EISSN: $2580-1481$

This page intentionally be emptied.

Gilang Ramadhan Fajri. The Analysis of The Effects of Capital Adequacy Ratio, Operational Cost Comparing to The Operational Revenue, Net Interest Margin, Non-Performing Loan and Loan to Deposit Ratio upon The Return On Equity (Empirical Study of Company Banking Registered in The List of BEI for The Period of 2012-2015) 